\title{
A thermophilic nitrate-reducing bacterium isolated from production water of a high temperature oil reservoir and its inhibition on sulfate-reducing bacteria
}

\author{
Jin-Feng Liu ${ }^{1,4}$, Wei-Lin Wu ${ }^{2}$, Feng Yao ${ }^{2}$, Biao Wang ${ }^{2}$, Bing-Liang Zhang ${ }^{1}$, Serge Maurice \\ Mbadinga, ${ }^{1,4}$ Ji-Dong $\mathrm{Gu}^{3}$ and Bo-Zhong Mu${ }^{1,4^{*}}$ \\ ${ }^{1}$ State Key Laboratory of Bioreactor Engineering and Institute of Applied Chemistry, East China University of Science \\ and Technology, Shanghai, People's Republic of China \\ ${ }^{2}$ Institute of Petroleum Engineering and Technology, Jiangsu Oilfield, Yangzhou 225009, Jiangsu Province, People’s \\ Republic of China \\ ${ }^{3}$ School of Biological Sciences, The University of Hong Kong, Pokfulam Road, Hong Kong, People’s Republic of China \\ ${ }^{4}$ Shanghai Collaborative Innovation Center for Biomanufacturing Technology, Shanghai 200237, People’s Republic of \\ China
}

\begin{abstract}
A thermophilic spore-forming facultative anaerobic bacterium, designated as Njiang2, was isolated from the production water of a high temperature oil reservoir $\left(8^{\circ} \mathrm{C}\right)$. The physiological, biochemical and $16 \mathrm{~S}$ rRNA gene based phylogenetic analysis indicated that Njiang2 belonged to the genus Anoxybacillus. Njiang2 could significantly inhibit $\mathrm{H}_{2} \mathrm{~S}$ production when co-cultured with Desulfotomaculum sp under laboratory conditions, which implied its great potential in mitigation of brine souring in the oil reservoir and in control of biocorrosion caused by sulfate-reducing bacteria. As far as we know, this might be the first report of Anoxybacillus sp. isolated from high temperature oilfield.
\end{abstract}

Keywords: Anoxybacillus, thermophilic, 16S rRNA gene analysis, nitrate-reducing bacterium, souring mitigation, microbial influenced corrosion

*Correspondence to: Bo-Zhong Mu, State Key Laboratory of Bioreactor Engineering and Institute of Applied Chemistry, East China University of Science and Technology, Shanghai 200237, People’s Republic of China; E-mail: bzmu@ecust.edu.cn

Received: February 19, 2016 ; Accepted: July 7, 2016 ; Published Online: November 17, 2016

Citation: Liu J-F, Wu W-L, Yao F, et al. 2016, A thermophilic nitrate-reducing bacterium isolated from production water of a high temperature oil reservoir and its inhibition on sulfate-reducing bacteria. Applied Environmental Biotechnology, vol.1(2): 35-42.

http://dx.doi.org/10.26789/AEB.2016.02.004.

\section{Introduction}

$\mathrm{O}$ il reservoir souring and microbial induced/ influenced corrosion (MIC), mainly caused by sulfate-reducing bacteria (SRB), are being given more and more attentions by the oil industry, and control on the growth and activity of SRB is of great importance. Studies demonstrate that supplement of nitrate to injection water is an effective me- thod to inhibit $\mathrm{H}_{2} \mathrm{~S}$ production and control the activities of SRB in the oil production system. Nitrate addition can stimulate the nitrate-reducing bacteria (NRB), a competitive group of anaerobic bacteria, which outcompete SRB and hence suppress the activities of SRB and/or remove sulfide ${ }^{[1-3]}$.

The mechanism on the mitigation of souring by injection of nitrate or nitrite has been investigated ${ }^{[4-10]}$. Obviously, NRB plays an important role in mitigation

A thermophilic nitrate-reducing bacterium isolated from production water of a high temperature oil reservoir and its inhibition on sulfate-reducing bacteria. (C) 2016 Jin-Feng Liu, et al. This is an Open Access article distributed under the terms of the Creative Commons Attribution-NonCommercial 4.0 International License (http://creativecommons.org/licenses/by- nc/4.0/), permitting all non-commercial use, distribution, and reproduction in any medium, provided the original work is properly cited. 
souring and control of MIC, and more and more attentions have been paid to the investigation and isolation of nitrate-reducing bacteria inhabiting in oil reservoirs recently. Up to now, various microorganisms capable of reducing nitrate have been isolated from oil reservoirs, including Geobacillus ${ }^{[11]}$, Deferribacter thermophiles $^{[12]}$, Anaerobaculum thermoterrenum ${ }^{[13]}, M a-$ rinobacter aquaeole ${ }^{[14]}$, Denitrovibrio acetiphilus ${ }^{[15]}$, Garciella nitratireducens ${ }^{[16]}$, Thauera and Sulfurospirillum spp. ${ }^{[9]}$, Marinobacter, Marinobacterium, and Halomonas spp. ${ }^{[17]}$. More recently, the nitrate-reducing community has been investigated based on PCR amplification of napA genes and nitrate-reducing bacterial communities have been recognized to be of rich diversity in production water from oil reservoirs ${ }^{[18]}$. However, the current knowledge about physiological properties of these nitrate-reducing bacteria is still limited.

Considering the generally anaerobic and thermophilic property of oil reservoirs underground, thermophilic nitrate-reducing anaerobes or facultative anaerobes have great potential in mitigating oil reservoir souring. This study mainly focuses on the isolation and evaluation of thermophilic nitrate-reducing bacteria from high temperature oil reservoir, and the morphological, physiological and phylogenetic characteristics as well as cellular fatty acids. Inhibition activity to SRB was also tested under laboratory conditions.

\section{Materials and Methods}

\subsection{Sample Collection}

Oil/water mixture sample from the H88 block (2400 $\mathrm{m}$ of depth, $87^{\circ} \mathrm{C}$ ), Jiangsu Oilfield, China, was taken directly from production well-heads into sterile 500 $\mathrm{ml}$ serum bottles, and immediately sealed with rubber stoppers before transporting back to our laboratory. The water phase, after separated from oil, was used for bacteria isolation. The high salinity production water was mainly composed of chloride, sulfate, potassium and sodium. The main characteristics of the samples are presented in Table 1.

\subsection{Enrichment and Isolation}

For the enrichment of microorganisms, the basal medium was used $\left(\mathrm{g} \cdot \mathrm{L}^{-1}\right.$ ) which contains: sodium acetate 3.0, $\mathrm{KCl} 0.33, \mathrm{MgCl}_{2} \cdot 6 \mathrm{H}_{2} \mathrm{O} 0.33, \mathrm{NH}_{4} \mathrm{Cl} 0.33, \mathrm{NaCl}$ 5.0, $\mathrm{KH}_{2} \mathrm{PO}_{4} 0.33, \mathrm{CaCl}_{2} \cdot 2 \mathrm{H}_{2} \mathrm{O} 0.02$, yeast extract 0.5 , $\mathrm{NaHCO}_{3} 0.3, \mathrm{KNO}_{3} 2.0, \mathrm{Na}_{2} \mathrm{~S} \cdot 9 \mathrm{H}_{2} \mathrm{O} 0.5$, Vitamin solution $3.0 \mathrm{~mL}$, trace element solution $3.0 \mathrm{~mL}$. The vitamin solution contained (mg/L): pyridoxine- $\mathrm{HCl}, 100$; nicotinic acid, 50.0; thioctic acid, 50.0; aminobenzoic
Table 1. Characteristics of sample collected from high temperature Jiangsu oil reservoir

\begin{tabular}{lc}
\hline \multicolumn{1}{c}{ Item } & Value \\
\hline Depth $(\mathrm{m})$ & 2400 \\
Temp $\left({ }^{\circ} \mathrm{C}\right)$ & 87 \\
Water flooding time (years) & 3 \\
Mineralization & 15165 \\
Water type & $\mathrm{NaHCO}_{3}$ \\
$\mathrm{pH}$ & 6.6 \\
$\mathrm{Cl}^{-}\left(\mathrm{mg} \cdot \mathrm{L}^{-1}\right)$ & 4953.1 \\
$\mathrm{SO}_{4}{ }^{2-}\left(\mathrm{mg} \cdot \mathrm{L}^{-1}\right)$ & 2924.6 \\
$\mathrm{PO}_{4}{ }^{3-}\left(\mathrm{mg} \cdot \mathrm{L}^{-1}\right)$ & 4.30 \\
$\mathrm{NO}_{3}{ }^{-}\left(\mathrm{mg} \cdot \mathrm{L}^{-1}\right)$ & 25.3 \\
$\mathrm{~K}^{+}, \mathrm{Na}^{+}\left(\mathrm{mg} \cdot \mathrm{L}^{-1}\right)$ & 5329.4 \\
$\mathrm{Ca}^{2+}, \mathrm{Mg}^{2+}\left(\mathrm{mg} \cdot \mathrm{L}^{-1}\right)$ & 40.84 \\
$\mathrm{~S}^{2-}\left(\mathrm{mg} \cdot \mathrm{L}^{-1}\right)$ & 57.7 \\
\hline
\end{tabular}

acid, 50.0; thiamine-HCl, 50.0; p-Ca-D(+)-pantothenate, 50.0; riboflavin, 50.0; folic acid, 20.0; $\mathrm{D}(+)$-biotin, 20.0; and vitamin B12, 1.00. Vitamin and trace element stocks solutions were made according to Wang et $a l .{ }^{[19]}$. The medium was prepared and autoclaved and then put under positive pressure of flow of nitrogen anaerobically and its $\mathrm{pH}$ was adjusted to 7.0 with $\mathrm{NaOH}$ or $\mathrm{HCl}$ before dispensation into $120 \mathrm{~mL}$ serum bottles with the headspace $(20 \mathrm{~mL})$ purged and filled with pure $\mathrm{N}_{2}$.

The enrichment was conducted by inoculation of the produced water sample $(10 \% \mathrm{v} / \mathrm{v})$ into the basal medium and then incubation at $60^{\circ} \mathrm{C}$ for 6 days. The fresh culture obtained was inoculated in the same medium and incubated under the same conditions and these procedures repeated for 3 times before it was used for microbial isolation.

The pure isolate was obtained after serial dilution and confirmed by its uniformity both in micromorphological appearance and macromorphological colonies formed anaerobically on solid medium (basal medium supplemented with 1.5\% Gellan Gum, Sigma) in Hungate tubes at $60^{\circ} \mathrm{C}$.

\subsection{Morphological and Physiological Characterization}

Cellular morphology was determined by light microscope, and colony morphology was determined with colonies formed anaerobically on solid medium at $60^{\circ} \mathrm{C}$. The formation of spores was observed with culture after 5 days of incubation. To determine optimal growth temperature, salinity and $\mathrm{pH}$, incubation experiments were performed with basal medium in- 
oculated with isolated strain under anaerobic conditions. The temperature range was determined by incubation test at different temperature ranging from $45^{\circ} \mathrm{C}$ to $70^{\circ} \mathrm{C}$ with $5^{\circ} \mathrm{C}$ intervals. In order to determine the optimum $\mathrm{NaC} 1$ concentration for growth, the concentration of $\mathrm{NaC} 1$ in the basal medium were set to be $2.0,3.0,4.0,5.0,8.0$, and $10.0 \%(\mathrm{w} / \mathrm{v})$ while that of the other components of the medium were kept unchanged. The $\mathrm{pH}$ range of growth was examined with cultivation test on Nutrient Broth medium with $\mathrm{pH}$ from 5.0 to 10.0 at an interval of $1.0 \mathrm{pH}$ unit. These physiological studies were conducted in constant temperature incubators without shaking at $60^{\circ} \mathrm{C}$. Growth was determined by measuring the optical density of the culture medium spectrophotometrically at $600 \mathrm{~nm}$.

The ability of Njiang2 in utilizing different carbohydrates was examined by incubation in the Peptone Water Medium with carbohydrate at a final concentration of $0.75 \%-1 \%(w / v)$ under aerobic conditions. The carbon source, D-cellobiose, D-fructose, L-rhamnose, L-arabinose, L-D-xylose, glucose, sucrose, $\alpha$-lactose, mannose, L-sorbose, D-ribose, D-galatose, D-mannitol, sorbitol, and starch were separately sterilized as stock solutions. Gram staining, hydrolysis of starch, gelatin and casein, citrate and urea utilization, reduction of nitrate to nitrite, Voges-Proskauer test, Methyl red test, indole and hydrogen sulfide production tests were carried out by the methods according to Microbiology Experiment ${ }^{[20]}$. Air bubble production using 3\% (v/v) $\mathrm{H}_{2} \mathrm{O}_{2}$ solution was used for evaluating the activity of catalase. The oxidase reaction was examined with agar plate containing $1 \%(\mathrm{w} / \mathrm{v}) \mathrm{N}, \mathrm{N}, \mathrm{N}^{\prime}, \mathrm{N}^{\prime}$ - tetramethyl-pphenylenediamine ${ }^{[21]}$.

\subsection{S rRNA Gene Sequencing and Phylogenetic Analysis}

The extraction and purification of DNA was performed using AxyPrep ${ }^{\mathrm{TM}}$ Bacterial Genomic DNA Miniprep Kit (Axygen Bioscience, Inc., CA, USA) according to the manufacturer's protocol. Resulting genomic DNA was immediately preserved at $-20^{\circ} \mathrm{C}$ before usage. The 16S rRNA gene was amplified by PCR using 27F (5 -AGAGTTTGATCCTGGCTCA-3') and 1492R (5 -GGTTACCTTGTTACGACTT-3') primers with the program as follows: initial denaturation at $95^{\circ} \mathrm{C}$ for $180 \mathrm{sec}, 30$ cycles of $94^{\circ} \mathrm{C}$ for $40 \mathrm{sec}$, annealing at $52^{\circ} \mathrm{C}$ for $45 \mathrm{sec}$, and $72^{\circ} \mathrm{C}$ for $90 \mathrm{sec}$, and a final elongation step of $72^{\circ} \mathrm{C}$ for $10 \mathrm{~min}$. Two replicates of $25 \mu \mathrm{L}$ PCR reaction mixture were made, each of which contains $2 \times \mathrm{PCR}$ MasterMix $2 \mu \mathrm{L}, \mathrm{ddH}_{2} \mathrm{O} 11$ $\mu \mathrm{L}$, two primers $1 \mu \mathrm{L}$, respectively and template DNA $2 \mu \mathrm{L}$. The sequence of the PCR products of 16S rRNA gene was determined by BGI sequencing company after purification. The results are presented as a phylogenetic tree which was made with MEGA version 5.0. The tree was rooted with 16S rRNA gene sequence from Geobacillus thermodenitrificans. 16S rRNA gene from Njiang2 is available in NCBI under the accession number KF421130.

\subsection{G+C Content Determination and Cellular Fatty Acid Analysis}

The genomic DNA of Njiang2 was extracted from overnight culture with basal medium mentioned above and purified before the determination of $\mathrm{G}+\mathrm{C}$ content by thermal denaturation temperature method ${ }^{[22]}$ using Escherixchia coli DNA as standards. Denaturation profiles were determined at $260 \mathrm{~nm}$ using a thermo-programmable Lambda35 UV/VIS spectrophotometer equipped with a temperature controller.

We used the Sherlock Microbial Identification System (MIDI) to determine the cellular phospholipid composition of Njiang2. Briefly, fresh cells in the mid-exponential phase were collected and put into a clean glass tube. The glass tube containing cells was then added with $1.0 \mathrm{~mL}$ saponification solution (45 g

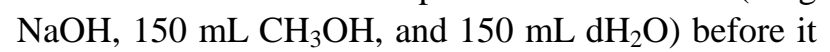
was vortexed for 5-10 s and afterwards heated in a boiling water bath at $100{ }^{\circ} \mathrm{C}$ for $30 \mathrm{~min}$. After saponification, the tube was added with $2.0 \mathrm{~mL}$ methylating reagent (a mixture of $275 \mathrm{~mL}$ methyl alcohol and $325 \mathrm{~mL} 6.0 \mathrm{~N}$ hydrochloric acid), and placed in $80^{\circ} \mathrm{C}$ water bath for $10 \mathrm{~min}$ for methyl esterification. The esterified mixture, after cooled to room temperature, was extracted with $1.25 \mathrm{~mL}$ extraction reagent (200 $\mathrm{mL}$ methyl tert-butyl ether and $200 \mathrm{~mL}$ hexane) and the extracts were collected and washed with 3.0 $\mathrm{mL}$ base solution (10.8 $\mathrm{g} \mathrm{NaOH}$ dissolved in $900 \mathrm{~mL}$ $\mathrm{dH}_{2} \mathrm{O}$ ) before GC analysis. Cellular Fatty Acid Methyl Esters (CFAMEs) were identified and quantified with Sherlock Microbial Identification System Software (V6.0).

\subsection{Inhibition of Sulfide Production by SRB}

To evaluate the ability of Njiang2 in inhibition of SRB for its sulfide production, incubation experiment with 3 treatments were conducted: (1) SRB only, (2) SRB+ nitrate, and (3) SRB + nitrate+Njiang2. The SRB used here was Desulfotomaculum sp, a typical SRB isolated from Jiangsu Oilfield, and the incubation medium was 
composed of $\left(\mathrm{g} \cdot \mathrm{L}^{-1}\right): \mathrm{Na}_{2} \mathrm{SO}_{4} 1.25, \mathrm{MgCl}_{2} \cdot 6 \mathrm{H}_{2} \mathrm{O} \quad 0.33$, $\mathrm{KH}_{2} \mathrm{PO}_{4}$ 0.33, $\mathrm{CaCl}_{2} 0.02, \mathrm{NH}_{4} \mathrm{Cl} 0.50$, KCl 0.33, yeast extract $0.10, \mathrm{C}_{3} \mathrm{H}_{5} \mathrm{O}_{3} \mathrm{Na} 3.50, \mathrm{NaCl} 5.0, \mathrm{~L}-$ Cysteine hydrochloride anhydrous $0.20, \mathrm{Na}_{2} \mathrm{~S} \cdot 9 \mathrm{H}_{2} \mathrm{O}$ 0.5 , Resazurin 0.002. All these experiments were conducted at $65^{\circ} \mathrm{C}$ and the $\mathrm{H}_{2} \mathrm{~S}$ produced was determined by colorimetric method ${ }^{[23]}$ briefly as follows: 0.5 $\mathrm{mL}$ sample solution taken was transferred into a tube, followed by $5 \mathrm{~mL}$ of zinc acetate solution $\left(20 \mathrm{~g} \cdot \mathrm{L}^{-1}\right)$. The obtained mixture was placed in a water bath maintained at $20^{\circ} \mathrm{C}$ for $10 \mathrm{~min}$, followed by addition of $1.0 \mathrm{~mL}$ of $\mathrm{N}, \mathrm{N}$-dimethyl para-phenylenediamine hydrochloric acid solution $\left(1.0 \mathrm{~g} \cdot \mathrm{L}^{-1}, 40 \%\right.$ hydrochloric acid solution as solvent), after which $2.0 \mathrm{~mL}$ of ferric chloride solution $\left(27 \mathrm{~g} \cdot \mathrm{L}^{-1}, 40 \%\right.$ hydrochloric acid solution as solvent) were added and blended. The mixture was placed into the water bath at $20^{\circ} \mathrm{C}$ for 10 min. Then, zinc acetate solution was added to the mixture to make the final volume to $10.0 \mathrm{~mL}$ before it was analyzed spectrophotometrically at $670 \mathrm{~nm}$. Every treatment was conducted with three replicates and the mean value was presented.

\subsection{Resistance to Antibiotics}

The ability of Njiang2 to resist antibiotics was evaluated by Sensi-discs method ${ }^{[24]}$ on Nutrient agar plates containing $1.8 \%$ agar (w/v). The filter-sterilized antibiotics (all at $10 \mu \mathrm{g} \cdot \mathrm{L}^{-1}$ ) of Penicillin, Chloramphenicol, Streptomycin, Vancomycin, Gentamicin, Erythromycin and Kanamycin were used. After these plates were incubated at $60^{\circ} \mathrm{C}$ for $24 \mathrm{~h}-48 \mathrm{~h}$, zones of inhibition were measured.

\section{Results}

\subsection{Phenotypic Characteristics}

All the phenotypic characteristics of strain Njiang2 are listed in Table 2. The Njiang2 colonies formed after cultivation on Nutrient Agar plates for $16 \mathrm{~h}$ with appearance of cream, smooth and circular with a diameter of 2-3 mm. Cells of Njiang2 in liquid culture were stained Gram-positive, appeared as single, rods (0.3 $-0.5 \mu \mathrm{m}$ in diameter and $2.0-4.0 \mu \mathrm{m}$ in length). Growth of Njiang2 was observed at $45^{\circ} \mathrm{C}-70^{\circ} \mathrm{C}$ with an optimum at $65^{\circ} \mathrm{C}$, pH $6.0-9.0$ with an optimum at $\mathrm{pH} 7.0, \mathrm{NaC} 1$ concentrations of $0 \%-2.5 \%(\mathrm{w} / \mathrm{v})$, with an optimum rang of $0.5 \%-1 \%$.

This strain can use a wide variety of carbon sources including citrate, maltose, mannose, glucose, D-fru- ctose, sucrose, D-cellose, D-ribose, D-mannitol, D-xylose and starch for growth. However, no growth was observed with L-sorbinose, L-rhamnose, L-arabinose, $\alpha$-lactose, galactose and sorbitol as substrates. It is tested positive for oxidase, urease and catalase. Gelatin and starch could be hydrolyzed and nitrate be reduced to nitrite by the isolated strain. Njiang2 fails to hydrolyze lipid and casein and shows negative test in indole production, Methyl red and hydrogen sulfide production. The Voges-Proskauer test was positive. As showed in Table 2, this strain was distinguished from other closest neighbor Anoxybacillus species by some characteristics.

Table 2. Comparison of the phenotypic characteristics of strain Njiang2 and related species

\begin{tabular}{|c|c|c|c|c|c|}
\hline Characteristic & 1 & 2 & 3 & 4 & 5 \\
\hline Relation to $\mathrm{O}_{2}$ & $\begin{array}{c}\text { Facultative } \\
\text { anaerobe }\end{array}$ & Aerobe & $\begin{array}{l}\text { Facultative } \\
\text { anaerobe }\end{array}$ & $\begin{array}{c}\text { Facultative } \\
\text { anaerobe }\end{array}$ & $\begin{array}{c}\text { Facultative } \\
\text { anaerobe }\end{array}$ \\
\hline $\begin{array}{l}\text { Temperature } \\
\left({ }^{\circ} \mathrm{C}\right)\end{array}$ & $45-70$ & $55-67$ & $37-69$ & $37-70$ & $37-66$ \\
\hline $\begin{array}{l}\text { Optimum tem- } \\
\text { perature }\left({ }^{\circ} \mathrm{C}\right)\end{array}$ & $60-65$ & 65 & 60 & $55-60$ & $57-62$ \\
\hline $\mathrm{pH}$ & $6.0-9.0$ & $6.0-7.5$ & $5.5-9.5$ & $5.5-9.5$ & $5.7-9.9$ \\
\hline Optimum pH & 7.0 & 7.2 & $8.0-9.0$ & 7.0 & 6.8-8.5 \\
\hline $\mathrm{NaCl}(3 \%, \mathrm{w} / \mathrm{v})$ & - & - & + & - & ND \\
\hline Motility & - & + & + & + & + \\
\hline \multicolumn{6}{|l|}{ Hydrolysis } \\
\hline Gelatin & + & - & + & + & - \\
\hline Starch & + & - & + & - & - \\
\hline Casein & - & - & ND & ND & - \\
\hline Oxidase & + & - & + & + & - \\
\hline Catalase & + & + & + & + & - \\
\hline $\begin{array}{l}\text { Nitrate } \\
\text { reduction }\end{array}$ & + & - & + & + & ND \\
\hline \multicolumn{6}{|l|}{$\begin{array}{l}\text { Substrates } \\
\text { utilized }\end{array}$} \\
\hline L-Arabinose & - & ND & - & - & - \\
\hline D-xylose & + & - & - & + & - \\
\hline Glucose & + & - & + & + & + \\
\hline Sucrose & + & - & ND & - & + \\
\hline$\alpha$-lactose & - & - & - & - & - \\
\hline Mannose & + & - & + & - & - \\
\hline D-ribose & + & - & ND & ND & + \\
\hline D-galactose & + & - & + & ND & ND \\
\hline D-mannitol & + & ND & + & - & + \\
\hline
\end{tabular}

1, strain Njiang2; 2, A. thermarum DSM $17141^{\mathrm{T}[25]} ; 3$, A. Salavatiensis DSM $22626^{\mathrm{T}[26]} ; 4$, A. gonensis NCIMB $13933^{\mathrm{t}[27]} ; 5$, A. Kamchatkensis DSM $14988^{\mathrm{T}[28]}$; + Positive, - Negative, ND not determined 


\subsection{Phylogenetic Analysis}

The 16S rRNA gene sequence of Njiang2 was compared with its closely related bacteria and the results are presented in phylogenetic tree (Figure 1). The new isolate had a sequence similarity ranging from $94 \%$ to 99\% with strains of Anoxybacillus species. Its closest relatives are A. thermarum DSM17141 ${ }^{\mathrm{T}}$, A. salavatliensis NCIMB $14579^{\mathrm{T}}$, A. gonensis NCIMB $13933^{\mathrm{T}}$, A. kamchatkensis DSM $14988^{\mathrm{T}}$ and the more distant one was A. voinovskiensis NCIMB $13956^{\mathrm{T}}$. According to $16 \mathrm{~S}$ rRNA gene sequence analysis, the new isolate was considered to be members of the genus Anoxybacillus.

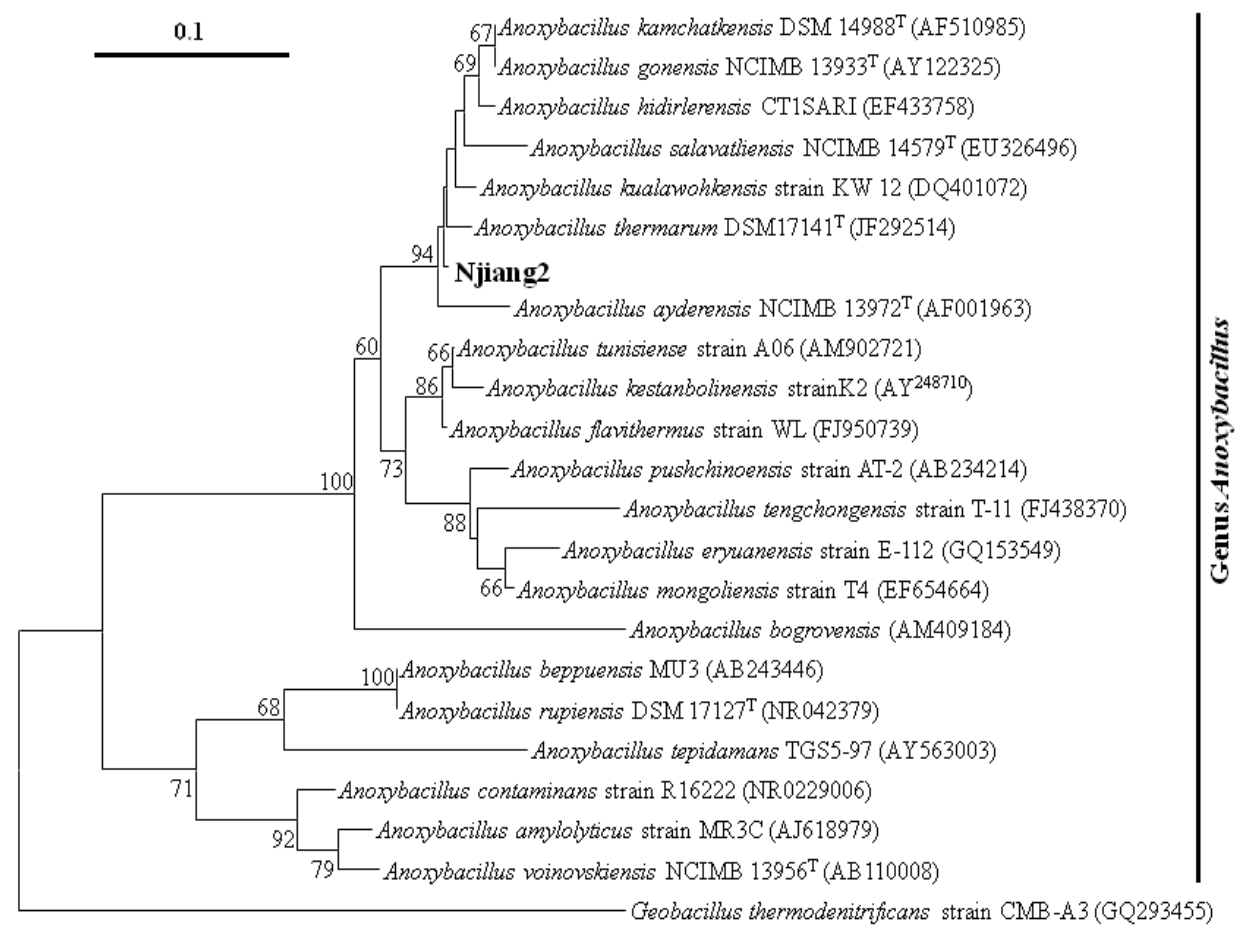

Figure 1. 16S rRNA gene based neighbor-joining phylo tree of strain Njiang2 and relatives from genus Anoxybacillus. The tree was rooted with Geobacillus thermodenitrificans. $10 \%$ substitutions per nucleotide position are given on the scale bar.

\subsection{G+C Content and Fatty Acid Composition}

The $\mathrm{G}+\mathrm{C}$ content was determined by thermal denaturation temperature method and the result showed that the DNA G+C content of Njiang2 was $48.8 \%$, which was different from its closest relatives A. gonensis (57\%), A. salavatiensis (45.1\%), A. kamchatkensis (42.3\%) and $A$. thermarum (53.5\%).

The results of phospholipid analysis are listed in Table 3. Njiang2 is composed mostly of branched saturated fatty acids and little amounts of anteiso-fatty acids. The main components of fatty acids are iso$\mathrm{C}_{15: 0}(33.4 \%)$ and iso- $\mathrm{C}_{17: 0}(25.7 \%)$, which agree well with fatty acid profiles of previously identified and published Anoxybacillus species. Iso- $\mathrm{C}_{15: 0}$, followed by iso- $\mathrm{C}_{17: 0}$ and anteiso- $\mathrm{C}_{17: 0}$ are the major fatty acids of Njiang2 and its closest relatives A. gonensis, A. salavatiensis and A. kamchatkensis. However, Njiang2 has high amounts of iso- $\mathrm{C}_{16: 0}$ and $\mathrm{C}_{16: 0}$, similar to
Table 3. Cellular fatty acid compositions of Njiang2 and related Anoxybacillus type strains

\begin{tabular}{|c|c|c|c|c|c|}
\hline Fatty acids & 1 & $2^{\mathrm{a}}$ & $3^{a}$ & $4^{a}$ & $5^{a}$ \\
\hline $\mathrm{C}_{14: 0}$ & - & 1.25 & - & - & 0.9 \\
\hline iso- $\mathrm{C}_{14: 0}$ & 1.48 & 1.18 & 5.19 & - & 1.6 \\
\hline iso- $\mathrm{C}_{15: 0}$ & 33.39 & 65.19 & 46.91 & 46.6 & 9.1 \\
\hline anteiso- $\mathrm{C}_{15: 0}$ & 2.04 & 2.64 & 2.81 & 2.9 & 7.7 \\
\hline $\mathrm{C}_{15: 0}$ & - & 1.12 & 0.42 & - & 2.6 \\
\hline iso- $\mathrm{C}_{16: 0}$ & 12.36 & 5.99 & 1.23 & 8.7 & 20.7 \\
\hline $\mathrm{C}_{16: 0}$ & 9.96 & 2.38 & 19.41 & - & 21.0 \\
\hline iso- $\mathrm{C}_{17: 0}$ & 25.74 & 11.96 & 15.80 & 6.6 & 9.3 \\
\hline anteiso- $\mathrm{C}_{17: 0}$ & 5.87 & 3.29 & 5.33 & 25.6 & 18.9 \\
\hline $\mathrm{C}_{18: 0}$ & 2.11 & - & 0.31 & - & 3.0 \\
\hline $\mathrm{C}_{18: 1 \delta 9}$ & 3.67 & 0.23 & - & - & - \\
\hline
\end{tabular}

Strains: 1, Njiang2; 2, A. gonensis NCIMB $13933^{\mathrm{T}} ; 3$, A. salavatiensis DSM $22626^{\mathrm{T}} ;$ 4, A. thermarum DSM $17141^{\mathrm{T}} ; 5$, A. kamchatkensis DSM $14988^{\mathrm{T}}$. a, Data from the corresponding reference of the concerning strain, as, A. gonensis NCIMB $13933^{\mathrm{T}[27]}$; A. salavatiensis DSM $22626^{\mathrm{T}[26]}$; A. thermarum DSM $17141^{\mathrm{T}[25]}$; A. kamchatkensis DSM $14988^{\mathrm{T}[28]}$. 
its closest relative $A$. thermarum. The contents of other fatty acids, such as iso- $\mathrm{C}_{14: 0}(1.48 \%)$, anteiso- $\mathrm{C}_{15: 0}$ (2.04\%) and $\mathrm{C}_{18: 0}(2.11 \%)$, are relatively low. In contrast, the content of $\mathrm{C}_{18: 189}$ is higher in Njiang2.

\subsection{Inhibition on Sulfide Production}

$\mathrm{H}_{2} \mathrm{~S}$ produced in 3 different incubation treatments at $65^{\circ} \mathrm{C}$ were determined and shown in Figure 2. It showed that the $\mathrm{H}_{2} \mathrm{~S}$ production in co-culture treatment of SRB and Njiang2 was negligible when compared to the SRB only and SRB with nitrate incubation treatments. The results of DGGE analysis of the microbial community in these 3 treatments also showed that the DNA bands corresponding to SRB appeared undetectable and those corresponding to Njiang2 were very strong, implying the fact that SRB was near completely inhibited by Njiang2.

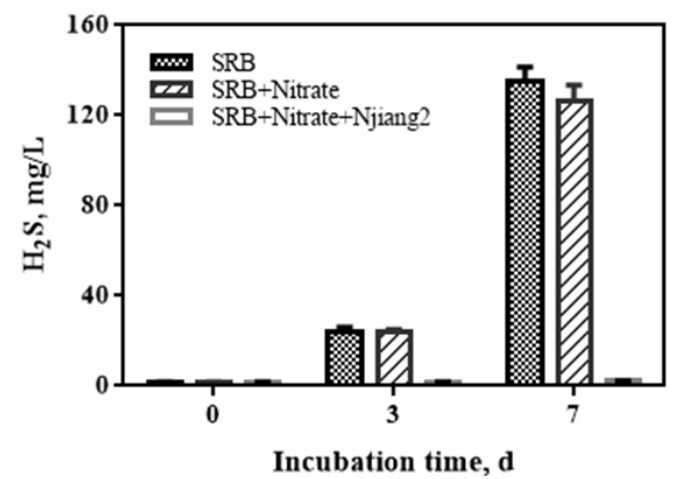

Figure 2. Production of hydrogen sulfide over incubation time under different treatments (Each data point is the mean of three replicates, mean values $\pm \mathrm{SD}, n=3$ ).

\subsection{Antibiotic Sensitivity}

Growth of Njiang2 was inhibited by Tetracycline, Streptomycin, Erythromycin, Gentamycin and Penicillin (each at $10 \mu \mathrm{g} \cdot \mathrm{L}^{-1}$ ) but not by chloramphenicol and Kanamycin (each at $10 \mu \mathrm{g} \cdot \mathrm{L}^{-1}$ ).

\section{Discussion}

Pikuta et al. first characterized the genus Anoxybacillus in 2000 and then the type strain of A. pushchinoensis was established. This strain was proposed as anaerobic bacterium and a further investigation showed that it was an aerotolerant anaerobe. At present, twenty species in this genus have been isolated and described, including A. gonensis ${ }^{[27]}$, A. Kamchatkensis $^{[28]}$, A. thermarum ${ }^{[25]}$, A. Salavatliensis ${ }^{[26]}$. Anoxybacillus species were usually isolated from geothermal environments. Here, we report a new isolate from a high temperature oil reservoir. The 16S rDNA sequence analysis showed the phylogenetic nature of genus Anoxybacillus of this isolate. To the best of our knowledge, this report is the first one on the isolation of Anoxybacillus from production water of oil reservoir.

There are only a few works reported on thermophilic nitrate-reducing bacteria isolated from oil reservoirs ${ }^{[11,12]}$. The typical NRBs are Geobacillus and Deferribacter. The genus Geobacillus can reduce nitrate anaerobically ${ }^{[11]}$. Genus Deferribacter is thermophilic and can anaerobically respirate with multiple electron acceptors. $D$. thermophilus could reduce manganese and iron by oxidation of organic acids, hydrogen, and complex substrates ${ }^{[12]}$. Njiang2 grows between $37^{\circ} \mathrm{C}$ and $70^{\circ} \mathrm{C}$ with an optimal growth at $65^{\circ} \mathrm{C}$, $\mathrm{pH} 6.0$ - 9.0 with an optimum at $\mathrm{pH} 7.0$, with $\mathrm{NaCl}$ concentration of $0 \%-2.5 \%(\mathrm{w} / \mathrm{v})$ (optimal $0.5 \%$ ) which shows good agreement with the in situ conditions of the original oil reservoir characteristics with temperature of $86^{\circ} \mathrm{C}-90^{\circ} \mathrm{C}$, mineralization of $15000 \mathrm{mg} / \mathrm{L}$ and $\mathrm{pH}$ of 6.5. Generally, the temperature of oil strata varies from injection well to production well and becomes lower after water injection for years. Thus, it is reasonable to consider Njiang2 as the likely indigenous microorganism to the oil reservoir where it was isolated.

Nitrate-reducing bacteria (NRB) are environmentally significant bacteria which can reduce nitrate in waters containing rich organic matter and nitrate and are frequently detected in oil reservoirs including heterotrophic NRB and sulfide-oxidizing, chemolithotrophic $\mathrm{NRB}^{[6]}$. One of the important properties of NRB is its inhibition activity towards SRB in oil reservoir which are believed to be chief culprits of Microbial Influenced Corrosion (MIC). The activities of NRB in oil reservoir can be stimulated by injection of nitrate and sulfide production by SRB consequently inhabited $^{[29]}$. Different NRBs play different roles, the heterotrophic NRB suppresses sulfide production by outcompeting heterotrophic SRB for substrates, whereas, the chemolithotrophic NRB, such as the NR-SOB (nitrate-reducing, sulfide-oxidizing bacteria), not only remove sulfide, but also suppress SRB for their sulfide production $^{[30]}$. Taking into consideration of the facultative and thermophilic growth characteristics and the ability to inhabit sulfide production by SRB even under anaerobic conditions, Njiang2 shows a great potential in mitigation of oilfield souring and on control of biocorrosion caused by SRB.

The result of 16S rRNA gene sequence analysis 
shows that Njiang2 is among the species of genera Anoxybacillus and has a similarity of $99 \%$ with sequences of $A$. thermarum DSM17141 ${ }^{\mathrm{T}}$. The difference in the $\mathrm{G}+\mathrm{C}$ content of Njiang2 (48.7\%) and $A$. thermarum DSM $17141^{\mathrm{T}}$ (53.5\%) is $4.8 \%$. Notably different phenotypic characteristics are found such as hydrolysis of starch and gelatin, oxidase activity, nitrate reduction reaction, as well as the utilization of sucrose, mannose, and D-mannitol (Table 2). Members of the genus Anoxybacillus are characterized by their fatty acid profile with the major component of iso-C15:0 and iso-C17:0 and Njiang2 is in agreement with this for iso-C15:0 (33.39\%) and iso-C17:0 (25.74\%). The composition of fatty acid is quite different between Njiang2 and A. thermarum DSM17141 ${ }^{\mathrm{T}}$ as shown in Table 3, especially in content of anteiso-C17:0 (5.87\% for Njiang2 and $25.6 \%$ for A. thermarum DSM17141 ${ }^{\mathrm{T}}$ ). Based on the phenotypic and biochemical differences mentioned above, Njiang2 is more likely a new species or subspecies of the genus Anoxybacillus.

\section{Conclusion}

Njiang2 is a thermophilic spore-forming facultative anaerobic bacterium isolated from high temperature oil reservoir. It is identified by its physiological, biochemical and phylogenetic characteristics to be a member of genus Anoxybacillus. Njiang2 can significantly inhibit $\mathrm{H}_{2} \mathrm{~S}$ production under laboratory conditions by Desulfotomaculum sp, a typical SRB isolated from Oilfield, which implied its great potential in mitigation of brine souring in the oil reservoir and on control of biocorrosion caused by SRB.

\section{Conflict of Interest and Funding}

No conflict of interest was reported by the authors. This work was financially supported by the National Natural Science Foundation of China (Grant No. 41273084, 41530318), the NSFC/RGC Joint Research Fund (No. 41161160560), the Research Foundation of Shanghai (No. 15JC1401400), and the China Petroleum and Chemical Corporation, Sinopec (P14071).

\section{References}

1. Telang A J, Ebert S, Foght J M, et al. 1997, Effect of nitrate injection on the microbial community in an oil field as monitored by reverse sample genome probing. Applied And Environmental Microbiology, vol.63(5): 1785-1793. http://dx.doi.org/10.1038/sj.jim.7000142.

2. Telang A J, Jenneman G E and Voordouw G, 1999, Sulfur cycling in mixed cultures of sulfide-oxidizing and sulfate- or sulfur-reducing oil field bacteria. Canadian Journal of Microbiology, vol.45(11): 905-913.

http://dx.doi.org/10.1139/w99-096.

3. Jenneman G E, Moffitt P D, Bala G A, et al. 1999, Sulfide removal in reservoir brine by indigenous bacteria. Spe Production \& Facilities, vol. 14(3): 219-225. http://dx.doi.org/10.2118/57422-PA.

4. Nemati M, Mazutinec T J, Jenneman G E, et al. 2001, Control of biogenic $\mathrm{H}_{2} \mathrm{~S}$ production with nitrite and molybdate. Journal of Indian Microbiology and Biotechnology, vol.26(6): 350-355. ttp://dx.doi.org/10.1038/sj.jim.7000142.

5. Eckford R E and Fedorak P M, 2002, Chemical and microbiological changes in laboratory incubations of nitrate amendment "sour" produced waters from three western Canadian oil fields. Journal of Indian Microbiology and Biotechnology, vol.29(5): 243-254. http://dx.doi.org/10.1038/sj.jim.7000304.

6. Eckford R E and Fedorak P M, 2002, Planktonic nitrate-reducing bacteria and sulfate-reducing bacteria in some western Canadian oil field waters. Journal of Indian Microbiology and Biotechnology, vol.29(2): 83-92. http://dx.doi.org/10.1038/sj.jim.7000274.

7. Greene EA, Hubert C, Nemati M, et al. 2003, Nitrite reductase activity of sulphate-reducing bacteria prevents their inhibition by nitrate-reducing, sulphide-oxidizing bacteria. Environmental Microbiology, vol.5(7): 607617. http://dx.doi.org/10.1046/j.1462-2920.2003.00446.x.

8. Hubert C, Nemati M, Jenneman G, et al. 2003, Containment of biogenic sulfide production in continuous up-flow packed-bed bioreactors with nitrate or nitrite, Biotechnology Progress, vol.19(2): 338-345.

http://dx.doi.org/10.1021/bp020128f.

9. Hubert C and Voordouw G, 2007, Oil field souring control by nitrate-reducing Sulfurospirillum spp. that outcompete sulfate-reducing bacteria for organic electron donors. Applied and Environmental Microbiology, vol.73(8): 2644-2652.

http://dx.doi.org/10.1128/aem.02332-06.

10. Grigoryan A A, Cornish S L, Buziak B, et al. 2008, Competitive oxidation of volatile fatty acids by sulfateand nitrate-reducing bacteria from an oil field in Argentina. Applied and Environmental Microbiology, vol.74(14): 4324-4335.

http://dx.doi.org/10.1128/aem.00419-08.

11. Nazina T N, Tourova T P, Poltaraus A B, et al. 2001, Taxonomic study of aerobic thermophilic bacilli: descriptions of Geobacillus subterraneus gen. nov., sp nov and Geobacillus uzenensis sp nov from petroleum reservoirs and transfer of Bacillus stearothermophilus, Bacillus thermocatenulatus, Bacillus thermoleovorans, Bacillus kaustophilus, Bacillus thermoglucosidasius and Bacillus thermodenitrificans to Geobacillus as the new combinations G-stearothermophilus, G-thermocatenula- 
tus, G-thermoleovorans, G-kaustophilus, G-thermoglucosidasius and G-thermodenitrificans. International Journal of Systematic and Evolutionary Microbiology, vol. 51433-51446.

http://dx.doi.org/10.1099/00207713-51-2-433.

12. Greene A D, Patel B K C and Sheehy A J, 1997, Deferribacter thermophilus gen. nov., sp. nov., a novel thermophilic manganese- and iron-reducing bacterium isolated from a petroleum reservoir. International Journal of Systematic Bacteriology, vol.47(2): 505-509.

http://dx.doi.org/10.1099/00207713-47-2-505.

13. Rees G N, Patel B K C, Grassia G S, et al. 1997, Anaerobaculum thermoterrenum gen. nov., sp. nov., a novel, thermophilic bacterium with ferments citrate. International Journal of Systematic Bacteriology, vol.47(1): 150-154.

http://dx.doi.org/10.1099/00207713-47-1-150.

14. Huu NB, Denner EBM, Ha DTC, et al. 1999, Marinobacter aquaeolei sp. nov., a halophilic bacterium isolated from a Vietnamese oil-producing well. International Journal of Systematic Bacteriology, vol.49: 367-375. http://dx.doi.org/10.1099/00207713-49-2-367.

15. Myhr S, Lillebo B L P, Sunde E, et al. 2002, Inhibition of microbial $\mathrm{H}_{2} \mathrm{~S}$ production in an oil reservoir model column by nitrate injection. Applied Microbiology and Biotechnology, vol.58(3): 400-408. http://dx.doi.org/10.1007/s00253-001-0881-8.

16. Miranda-Tello E, Fardeau M L, Sepulveda J, et al. 2003, Garciella nitratireducens gen. nov., sp nov., an anaerobic, thermophilic, nitrate-and thiosulfate-reducing bacterium isolated from an oilfield separator in the Gulf of Mexico. International Journal of Systematic and Evolutionary Microbiology, vol.53(5): 1509-1514. http://dx.doi.org/10.1099/ijs.0.02662-0.

17. Kumaraswamy R, Ebert S, Gray M R, et al. 2011, Molecular- and cultivation-based analyses of microbial communities in oil field water and in microcosms amended with nitrate to control $\mathrm{H}_{2} \mathrm{~S}$ production. Applied Microbiology and Biotechnology, vol.89(6): 2027-2038. http://dx.doi.org/10.1007/s00253-010-2974-8.

18. Feng W W, Liu J F, Gu J D, et al. 2011, Nitrate-reducing community in production water of three oil reservoirs and their responses to different carbon sources revealed by nitrate-reductase encoding gene (napA), International Biodeterioration \& Biodegradation, vol. 65(7): 1081-1086.

http://dx.doi.org/10.1016/j.ibiod.2011.05.009.

19. Wang L-Y, Gao C-X, Mbadinga S M, et al. 2011, Characterization of an alkane-degrading methanogenic enrichment culture from production water of an oil reservoir after 274 days of incubation. International Biodeterioration \& Biodegradation, vol.65(3): 444-450. http://dx.doi.org/10.1016/j.ibiod.2010.12.010.

20. Shen P, Fan X-R and Li G-W, 1999, Microbiology Experiment. High Education Press, Beijing.

21. Baek S H, Im W T, Oh H W, et al. 2006, Brevibacillus ginsengisoli sp nov., a denitrifying bacterium isolated from soil of a ginseng field. International Journal of Systematic Evolutionary and Microbiology, vol.56(11): 2665-2669.

http://dx.doi.org/10.1099/ijs.0.64382-0.

22. Marmur J and Doty P, 1962, Determination of the base composition of deoxyribonucleic acid from its thermal denaturation temperature. Journal of Molecular Biology, vol.5(1): 109-118.

http://dx.doi.org/10.1016/S0022-2836(62)80066-7.

23. Cline J D, 1969, Spectrophotometric determination of hydrogen sulfide in natural waters. Limnology and Oceanography, vol.14(3): 454-458.

http://dx.doi.org/10.4319/lo.1969.14.3.0454.

24. Flores A R, Parsons L M and Pavelka M S, 2005, Genetic analysis of the $\beta$-lactamases of Mycobacterium tuberculosis and Mycobacterium smegmatis and susceptibility to $\beta$-lactam antibiotics. Microbiology, vol.151(2): 521-532. http://dx.doi.org/10.1099/mic.0.27629-0.

25. Poli A, Romano I, Cordella P, et al. 2009, Anoxybacillus thermarum sp nov., a novel thermophilic bacterium isolated from thermal mud in Euganean hot springs, Abano Terme, Italy. Extremophiles, vol.13(6): 867-874. http://dx.doi.org/10.1007/s00792-009-0274-y.

26. Cihan A C, Ozcan B and Cokmus C, 2011, Anoxybacillus salavatliensis sp. nov., an $\alpha$-glucosidase producing, thermophilic bacterium isolated from Salavatli, Turkey, Journal of Basic Microbiology, vol.51(2): 136-146. http://dx.doi.org/10.1002/jobm.201000115.

27. Belduz A O, Dulger S and Demirbag Z, 2003, Anoxybacillus gonensis sp nov., a moderately thermophilic, xylose-utilizing, endospore-forming bacterium. International Journal of Systematic Evolution and Microbiology, vol.53(5): 1315-1320. http://dx.doi.org/10.1099/ijs.0.02473-0.

28. Kevbrin V V, Zengler K, Lysenko A M, et al. 2005, Anoxybacillus kamchatkensis sp nov., a novel thermophilic facultative aerobic bacterium with a broad $\mathrm{pH}$ optimum from the Geyser valley, Kamchatka. Extremophiles, vol.9(5): 391-398. http://dx.doi.org/10.1007/s00792-005-0479-7.

29. Gieg L, Jack T and Foght J, 2011, Biological souring and mitigation in oil reservoirs. Applied Microbiology and Biotechnology, vol.92(2): 263-282. http://dx.doi.org/10.1007/s00253-011-3542-6.

30. Jenneman G and Gevertz D, 1997, Sulfide-oxidizing bacteria, US Patent 5,686,293. 